\title{
Novel murine homeo box gene on chromosome 1 expressed in specific hematopoietic lineages and during embryogenesis
}

\author{
John D. Allen, Thierry Lints, Nancy A. Jenkins, ${ }^{1}$ Neal G. Copeland, ${ }^{1}$ Andreas Strasser, \\ Richard P. Harvey, and Jerry M. Adams \\ The Walter and Eliza Hall Institute of Medical Research, PO Royal Melbourne Hospital, Melbourne 3050, Australia \\ ${ }^{1}$ Mammalian Genetics Laboratory, ABL-Basic Research Program, National Cancer Insititue-Frederick Cancer Research and \\ Development Center, Frederick, Maryland 21702 USA
}

We describe here a new murine homeo box gene, denoted $H l x$, which is expressed within specific hematopoietic lineages. The cDNA sequence indicates that $\mathrm{Hl} \mathbf{x}$ differs markedly from known vertebrate homeo box genes, and linkage analysis of an interspecific murine backcross showed that it resides at a novel homeo box locus on the distal portion of mouse chromosome 1. The HIx homeo domain is most similar to that of the Drosophila H2.0 gene, but outside this region the two polypeptides are related only within a few short segments, the most notable being a motif (denoted Hep) also partially conserved in the engrailed and invected homeo proteins and possibly related to an octapeptide in certain paired box proteins. The presence of an intron within the Hlx homeo box at the same position as in several divergent Drosophila genes (H2.0, labial, Distal-less, proboscipedia, Abdominal-B, NK-1) suggests an ancient evolutionary relationship between these genes. RNA analysis of 67 murine hematopoietic cell lines and normal hematopoietic cells revealed $H / x$ expression throughout the myeloid/macrophage lineage and at early stages of $B$ lymphocyte development but not in T lymphocytes, erythroid cells, or mast cells. Hence, $\mathbf{H l x}$ is a candidate regulator of hematopoietic lineage commitment and maturation. It probably also functions outside the hematopoietic system, however, because Hlx mRNA could be detected in diverse adult tissues and in embryos from as early as day 8 of development.

[Key Words: Hematopoiesis; embryogenesis; homeo box evolution; gene mapping]

Received January 14, 1991; revised version accepted January 30, 1991.

The molecular control of differentiation processes such as lineage commitment and cellular maturation is likely to hinge upon lineage-restricted transcription factors that induce or repress batteries of subordinate genes. In vertebrates, most progress in identifying relevant factors has been made in myogenesis, where MyoD and its relatives play key roles (Davis et al. 1987). The unravelling of the intricate process of insect morphogenesis, however, has revealed that many pivotal genes encode the conserved DNA-binding homeo domain (Gehring 1987; Scott et al. 1989). Because some homeo proteins of Drosophila and of Caenorhabditis elegans participate in cell-type discrimination, the numerous vertebrate homeo box genes may well help to guide not only morphogenesis but also cellular differentiation processes, some of which continue throughout life.

Parallels between the vertebrate and insect homeo box genes are increasingly evident. The best-studied vertebrate class comprises the numerous Antennapedia $(A n t p)$-like Hox genes, which reside within at least four clusters of up to a dozen genes, located on separate chromosomes (Boncinelli et al. 1988; Kessel and Gruss 1990). Each cluster exhibits intriguing similarities with the complement of genes within the fly Antennapedia and Bithorax clusters, not only in homeo domain sequences but also in order of activation, anterior boundary of expression during embryogenesis, and possible role in segmentation (Graham et al. 1989; Kessel and Gruss 1990).

Several vertebrate homeo proteins have recently been identified as transcription factors required for expression of lineage-specific genes. For instance, Oct-2 is necessary for immunoglobulin expression by $\mathbf{B}$ lymphocytes (Müller et al. 1988), whereas Pit-1 (GHF-1), another member of the POU class, is associated with expression of several genes in the pituitary (Ingraham et al. 1988). Similarly, LF-B1 (HNF-1, APF) is involved in the expression of liver-specific genes (Frain et al. 1989; Baumhueter et al. 1990), and TTF-1 in that of thyroid-specific genes (Guazzi et al. 1990). Finally Isl-1, which is more similar to two differentiation-controlling homeo proteins of $C$. 
elegans than to any other vertebrate homeo protein, is required for insulin expression in the pancreas (Karlsson et al. 1990). Because all of these genes have homeo boxes very different from those of the Antp class, the more divergent members of the homeo box family may figure prominently in the control of cell type-specific gene expression.

Our focus is the intrinsic control of hematopoiesis. Because at least eight diverse lineages of mature cells are continuously generated from self-renewing hematopoietic stem cells (Metcalf 1988), many developmental decisions must be made. A major experimental asset of this system is the availability of numerous murine cell lines representative of several lineages and stages of maturation. The lines obviate the problem of obtaining pure cell populations from normal tissues and facilitate detection of the low-abundance mRNAs expected for many regulatory genes. To explore potential homeo box gene involvement in hematopoiesis, our laboratory has been screening cDNA libraries for homeo box clones and investigating their expression within such cell lines (Kongsuwan et al. 1988).

A homeo box gene with expression restricted to particular hematopoietic lineages would be of particular interest as a candidate commitment gene. We report the characterization of a novel murine homeo box gene derived from a chromosomal locus distinct from the known murine homeo box loci. It is expressed in cells of myeloid-macrophage lineage and at early stages of Blymphocyte development, as well as during embryogenesis. Its homeo box sequence is divergent from those of the known vertebrate genes but is closely related to that of the Drosophila H2.0 gene, one of the few fly genes that exhibit only tissue-specific expression (Barad et al. 1988). To indicate this sequence relationship, the new gene will be denoted $H I x$, for $\underline{H} 2.0$-like homeo box gene. The presence of an intron within the Hlx homeo box at the same position as in a number of diverse homeo box genes of Drosophila and C. elegans has implications for the evolution of the homeo box gene family.

\section{Results}

\section{Isolation of a new homeo box $c D N A$ and its cognate gene}

To identify homeo box genes expressed during lymphopoiesis, a cDNA library from the pre-B cell line 70Z/ 3 was screened by hybridization at low stringency with a mixture of oligonucleotides from the most conserved region of the homeo box, the third helix (Scott et al. 1989). From 600,000 plaques, 18 positive clones were obtained. The presence of a homeo box in each clone was verified by sequencing from a primer complementary to the Antp third helix (see Materials and methods). Thirteen clones derived from genes of the Hox-2 cluster (Hox-2.1, Hox2.2, Hox-2.4) and will not be discussed further here. The remaining five clones represented the novel homeo box gene denoted Hlx. The 70Z/3 cDNAs (e.g., j15 in Fig. 1), together with additional clones subsequently isolated from a macrophage cDNA library (e.g., $\mathrm{ml}, \mathrm{m} 3$ ), have

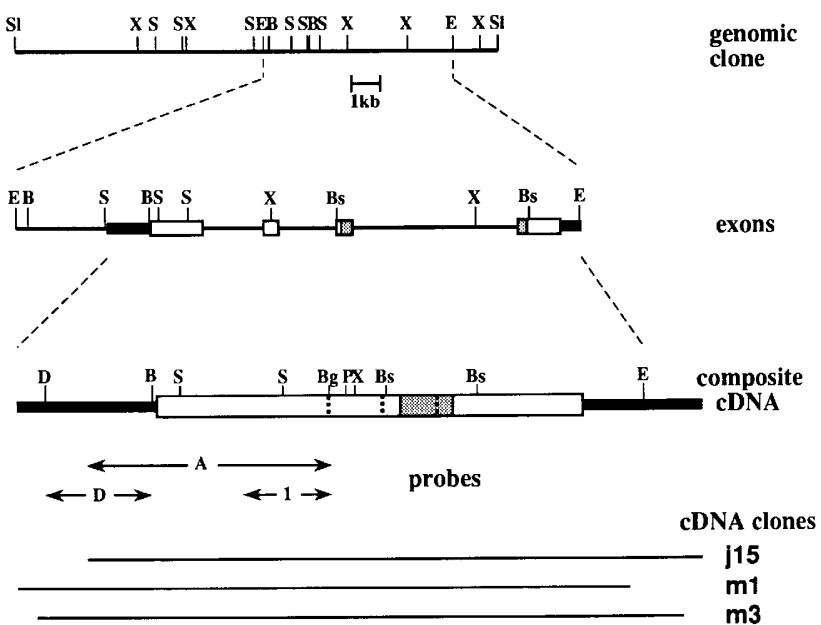

Figure 1. Structure of $H l x$ genomic clone, an EcoRI subclone, and cDNA clones. The four exons are boxed; the homeo box is shaded; exon junctions in the cDNA are marked. Probes A, D, and 1 are indicated. Restriction sites are coded as $(B) B a m H_{i}$ (Bg) BglII; (Bs) Bsp1286, (D) DraI; (E) EcoRI; (P) PstI; (S) SmaI (S1) Sall; and (X) XbaI. The j15 cDNA clone derived from the $70 \mathrm{Z} / 3$ library; $\mathrm{ml}$ and $\mathrm{m} 3$ are from the macrophage cDNA library.

allowed us to determine a sequence representing $2.3 \mathrm{~kb}$ of the estimated $2.7-\mathrm{kb} H \mathrm{l}_{\mathrm{x}}$ mRNA.

The Hlx gene was isolated from a $\lambda$ library, and its exons were defined by comparing genomic and cDNA restriction maps and by sequencing one strand of the indicated 6.3-kb EcoRI subclone (Fig. 1). Hlx has at least four exons and, unlike most vertebrate Hox genes, has an intron within the homeo box (solid box in Fig. 1). Significantly, its position (arrow in Fig. 2) is identical to that within the homeo boxes of 11 homeo box genes of Drosophila or C. elegans (see Discussion).

The Hlx cDNA sequence (Fig. 2), which extends to the poly(A) tract, predicts a polypeptide of 476 amino acids. The indicated methionine initiation codon has a moderately favorable context (Kozak 1987). The reading frame remains open for 98 codons upstream of the putative initiation codon to the in-frame stop at nucleotide 172 . No non-ATG initiation codon in a good context is evident in that region, but there are several potential splice acceptor sites. To address the possibility that alternative splicing might generate an Hlx RNA encoding an extended amino-terminal sequence, RNase protection experiments were performed with probe $D$ (Fig. 1) from the 5 '-untranslated region on mRNA from several cell types expressing $H l_{x}$ (see below), but no evidence of splicing was obtained.

The Hlx mRNA has a conspicuously long 5'-untranslated region. The 468-bp leader sequence shown in Figure 2 is unlikely to represent its full extent, since we estimate from the size of the mRNA (see below) that the $5^{\prime}$-untranslated region is likely to be $650-750 \mathrm{bp}$ long. The reported sizes of some other vertebrate homeo box mRNAs suggest that they may also bear long leaders, which may have some regulatory role. A curious feature of the Hlx $5^{\prime}$-untranslated sequence is the poly $(\mathrm{T})$ 

5

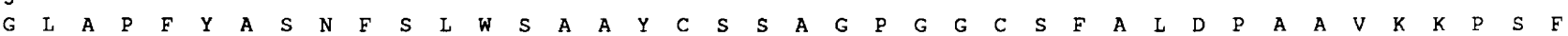
GGCCTGGCTCCCTTCTATGCTTCCAACTTTAGTCTCTGGTCAGCCGCCTACTGCTCCTCGGCGGGCCCGGGCGGCTGCTCCTTCGCCCTGGACCCAGCCGCTGTCAAGAAACCCTCTTTC

45

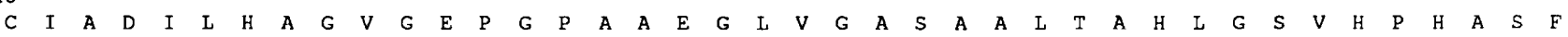
TGCATCGCGGACATCCTGCACGCCGGCGTCGGGGAGCCGGGGCCCGCTGCAGAGGGACTGGTGGGGGCCTCGGCAGCCCTCACCGCACACTTGGGCTCCGTGCACCCGCACGCCTCCTTC proline rich

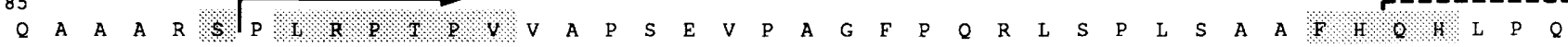
CAAGCTGCCGCCAGATCCCCGCTCCGTCCCACCCCGGT GGTGGCGCCCTCAGAAGTCCCGGCTGGCTTCCCTCAGCGGCTGTCTCCGCTCTCTGCCGCCTTCCACCAGCATCTCCCGCAG

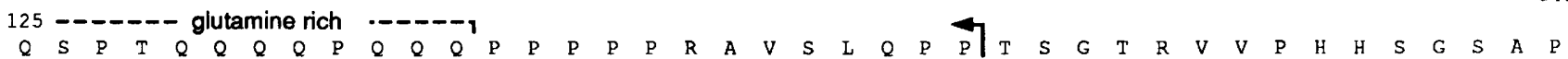
CAATCACCAACGCAGCAACAGCAACCGCAGCAGCAGCCCCCGCCTCCACCCCGGGCGGTCTCCCTGCAGCCACCGACTTCGGGGACGCGGGTGGTCCCCCACCATAGCGGCTCCGCCCCT 165

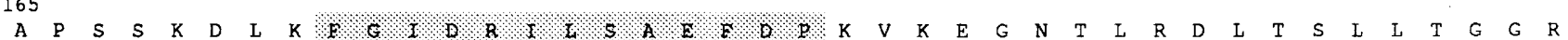
GCCCCCTCCAGCAAAGACCTCAAATTTGGTATCGATCGAATTTTGTCTGCGGAATTTGACCCAAAAGTTAAGGAAGGCAACACTCTGAGAGATCTCACATCGCTGCTAACCGGTGGGCGG 205
$P$ CCTGCAGGGTGCATCTAGCTGGCCTGCAGCCTTCAGCGGGACAGTTCTTCGCATCTCTAGATCCCATTAGCGAGGCGTCTGCCATCCTCAGCCCCTTAAGCTCCAACCCAAGAAATTCT 245

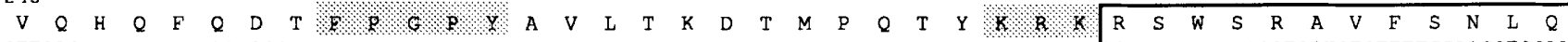
GTTCAGCATCAATTCCAAGACACATTTCCAGGTCCCTATGCTGTGCTCACTAAGGACACCATGCCACAGACATACAAGCGGAAQGGCTCGTGGTCCCGTGCTGTCTTTTCCAACCTGCAA AGAAAAGGCCTGGAGAAGAGGTTTGAGATCCAGAAGTACGTGACCAAGCCAGACCGAAAGCAGCTGGCGGCCATGCTGGGCCTCACGGATGCACAGGTGAAGGTGTGGTTCCAGAACCGG $\frac{325}{R}$

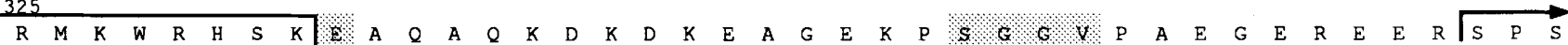
AGGATGAAGTGGCGGCACTCTAAGGAGGCGCAGGCGCAGAAGGACAAGGACAAGGAAGCGGGCGAGAAGCCTTCCGGCGGAGTCCCCGCCGAGGGTGAACGGGAGGAGAGGAGCCCCAGC 365 R S S E $G$ G CGTTCTGAGGGCGAAGCCGAGAGCGAGAGCAGTGACTCGGAGTCCCTGGACATGGCCCCCAGCGACACGGAACGGACTGAGGGAACGGAGAGGTCCCTGCATCAAACCACGGTCATCAAG 405

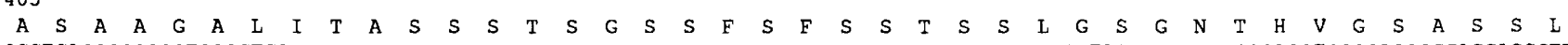
GCCTCAGCCGCGGGTGCCCTCATCACTGCCAGCAGCAGCACGAGTGGTAGCAGCTTCAGTTTCAGCAGCACCAGCAGCCTGGGTAGCGGCAACACCCACGTGGGGAGCGCCAGCAGCCTT 445 ser-thr rich

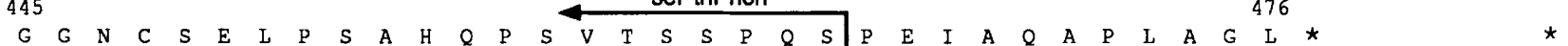
GGCGGCAACTGCTCGGAGCTGCCTTCGGCTCACCAGCCCTCAGTCACCAGCAGTCCTCAAAGCCCGGAGATCGCCCAGGCCCCGCTTGCAGGTTTATAGACTGGACCGAGGGCATAGCGT 1920 GCAGCTTCCTCTACACTGGCTGGACTTTGTGCCTACTTTAAGTTGGTGGCGAGGGTTGCCTAGATTGGAGCCGGACGCCACGGGCAGCCTCTTCGGGGTTCATACTTTTTCTCTTGCTGC CCCGGCTGCCAGAGCCCCCACCCCCGTCCGCCCAGTGGAGAGTTTTAAGGTTCCCCCTCCCCCGTCACAAAGAAAGAATTCAACTGTTTTCCCTACCTAAGCAGCTCACACTGTGAAATG 2160 TTCGGTGGAACTGTTCCTCTGAGCACCAGGGGTCTTGGCATAAGGACTTGCTGCACTTAGGAGGCCTTTAACTTGTAAATAMAATGTTTACTACGGTTTGTAAAAAAAAAAA. .. . 2261

Figure 2. Hlx cDNA sequence. Arrowheads denote positions of introns. The homeo box is boxed; other conserved regions mentioned in the text are shaded. In-frame stop codons are marked by asterisks $\left({ }^{\star}\right)$; the polyadenylation signal is boldface. This sequence has been submitted to the EMBL database.

tract; this is present in the genomic as well as the cDNA, clone and RNase protection analysis confirmed that it resides in Hlx mRNA.

$\mathrm{Hlx}$ is related to Drosophila $\mathrm{H} 2.0$ and bears a motif recognizable in engrailed and paired box genes

The predicted $H l_{x}$ polypeptide lacks the conserved amino-terminal sequence and the IYPWM pentapeptide "minibox" just upstream of the homeo domain of many vertebrate Hox genes (Boncinelli et al. 1988; Wright et al. 1989 |. Its homeo domain is remarkably similar to that of the Drosophila H2.0 gene (Fig. 3). Forty-nine of the 60 amino acids $(82 \%)$ are identical, as are several residues flanking the homeo domains. Homology is much more limited with other homeo domains; the nearest are 
Figure 3. Comparison of $H l_{x}$ homeo domain and flanking residues with those of several other homeo box genes. Shaded areas indicate identity with $H l_{x}$; dots indicate identity with Antp. The position of introns within a number of homeo boxes is indicated at the bottom (see Discussion). Drosophila genes include H2.O (M. Barad and W. McGinnis, pers. comm.); labial (lab) and proboscipedia ( $p b)$ (Mlodzik et al. 1988; Diederich et al. 1989); Distal-less (DII) (Cohen et al. 1989); Abdominal-B (Abd-B) (Celniker et al. 1989); NK-I (Kim and Nirenberg 1989); engrailed (en) (Poole et al. 1985), and invected (inv) (Coleman et al. 1987). The $C$.

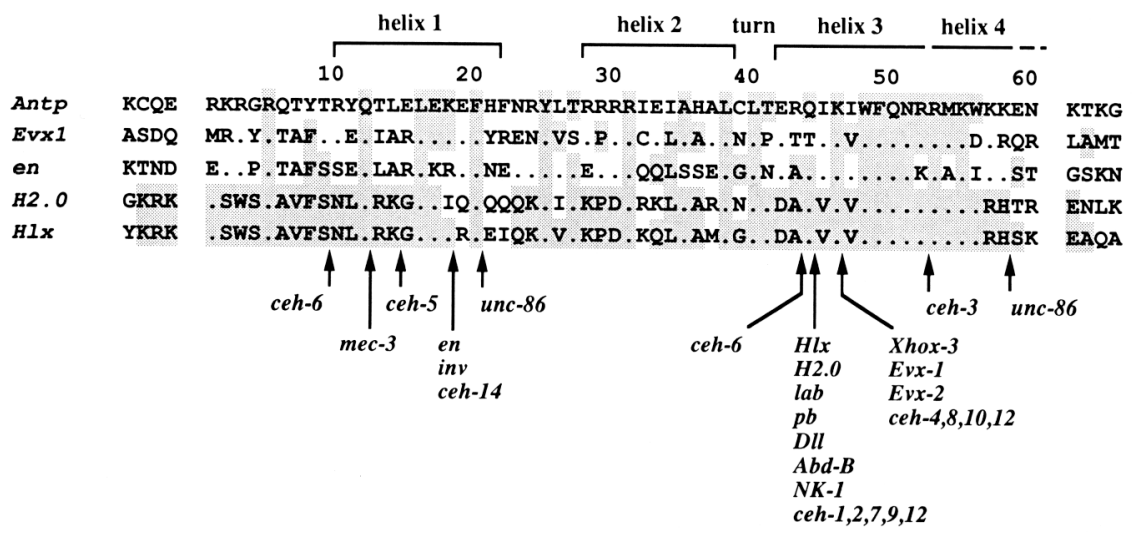

elegans genes (ceh, unc-86, mec-3) are cited in Schaller et al. (1990), Bürglin et al. (1989); and Hawkins and McGhee (1990); the vertebrate eve-like genes Xhox-3, by Ruiz i Altaba and Melton (1989); and Evx-1 and Evx-2, by Bastian and Gruss (1990). The ceh-14 gene and POU genes ceh- 6 and unc- 86 have two introns within the homeo box.

members of the even-skipped class such as Xenopus Xhox3 (Ruiz i Altaba and Melton 1989) and EVX-1 (Bastian and Gruss 1990), but their homology with $H l x(43 \%)$ is only slightly higher than that of Antp $(40 \%)$. Nevertheless, $H l_{x}$ is closely related to all Antp-like genes within the third helix, which is involved in DNA recognition (Scott et al. 1989). Hence Hlx might be regarded as a distant member of the Antp family. In current views of DNA-binding specificity (Hanes and Brent 1989), the preservation of glutamine at the ninth residue of that helix argues that $H l x$ may recognize target sequences similar to those of Antp-class homeo proteins, but an exception to that rule has been reported (Guazzi et al. 1990).

Outside the homeo domain, the similarity between $H l x$ and H2.O is confined to several short sequences (Fig. 4). These include a conserved SGGV tetrapeptide, 17 residues carboxy-terminal to the homeo domain and the EA ... SSDS stretch farther downstream (Fig. 2). Aminoterminal to the homeo domain, both genes contain the pentapeptide FPGPY and the sequence S-LRPTPI/V, followed 20 residues later by FHQH at the start of a glutamine-rich segment. These sequences were not found in any other protein within the computer data bases.

Remarkably, a larger segment within the amino-terminal portion of $H x_{x}$ has been partially conserved not only in $H 2.0$ but also in the engrailed class of homeo proteins and, to a lesser extent, in four genes bearing the paired box, a domain present in several regulatory genes and first found upstream of the paired homeo box gene (Bopp et al. 1986). Within the Hep (H2.0/engrailed/ paired) motif, Hlx shares 6 of the 13 most conserved amino acid residues with $\mathrm{H2}$ 2.0, 7 with engrailed, and 9 with invected; several of the differences represent conservative substitutions (Fig. 5). Within the central, more conserved segment, some homology is also evident with an octapeptide region noted previously in the two gooseberry homeo proteins of Drosophila and in two human genes that also carry a paired box (Burri et al. 1989), as well as in the murine Pax2 homeo protein (Dressler et al. 1990) whether the two human genes contain a ho- meo domain is not yet known. The occurrence of the Hep motif in these divergent putative regulatory genes suggests that it has a specific function. No convincing example of the motif was found by computer search in any other known gene.

Three other regions of $H l x$ might function in transcriptional activation. Downstream from the homeo box, both $H l x$ and $H 2.0$ have an acidic segment residing within a longer region rich in serine and threonine residues, which comprise $38 \%$ of that portion of $H l x$ (Figs. 2 and 4). The amino-terminal part of $H l_{x}$ has segments rich in proline and glutamine. In a number of transcription factors, such domains contribute to transcriptional activation (Mitchell and Tjian 1989).

\section{New homeo box locus on the distal portion of mouse chromosome 1}

The mouse chromosomal location of $H \mathrm{H}_{\mathrm{x}}$ was determined by interspecific backcross analysis. The panel of progeny used in this analysis, derived from mating (C57BL/6) $\times$ Mus spretus) $\mathrm{F}_{1}$ and C57BL/6) mice (Dickinson et al. 1990), has been typed for over 500 loci well distributed over all the autosomes and the $\mathrm{X}$ chromosome. To reveal informative restriction fragment length polymorphisms, C57BL/6I (Mus musculus) and M. spre-

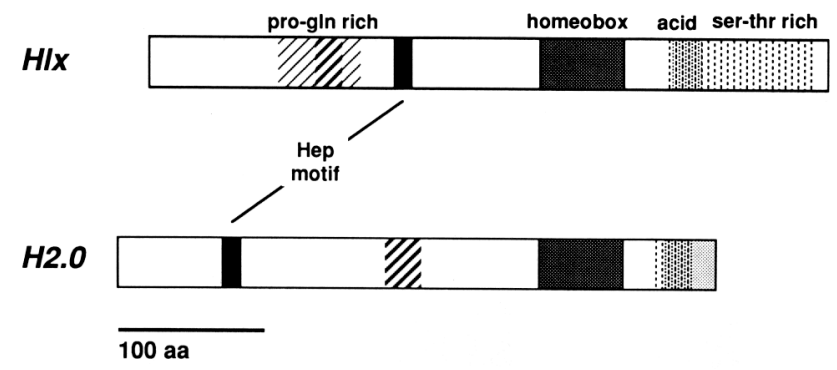

Figure 4. Features of the putative $H l x$ protein and comparison with $H 2.0$. 


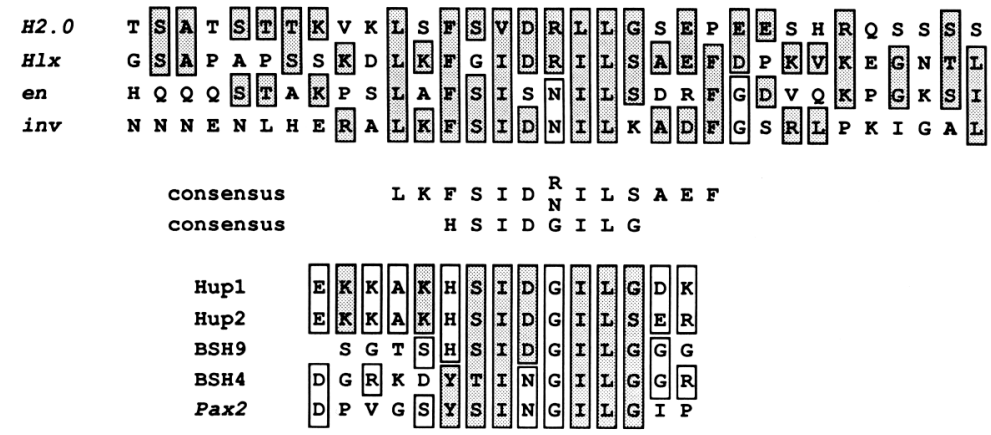

Figure 5. Conservation of the Hep motif in $H l x$ and other homeo proteins and comparison with a similar conserved segment in genes containing a paired box. Boxing indicates identical or very similar residues within a subgroup; shading denotes a residue identical or very similar to that in $H l x$ or $H 2.0$.

tus DNAs were first digested with several enzymes and analyzed by Southern blot hybridization using the $H l_{x}$ probe. A TaqI polymorphism (see Materials and methods) was then used to follow the segregation of the two Hlx alleles among backcross progeny. The results (Fig. 6, top/ mapped Hlx to the distal region of mouse chromosome 1, linked to the loci for transforming growth factor $\beta-2$ (Tgfb-2), $\alpha$-spectrin (Spna-1), and antithrombin-3 (At3). By allotyping each of these markers in at least 176 progeny, we derived their most likely gene order and the recombination distances between them (Fig. 6). No crossovers were detected between $T g f b-2$ and $H l x$, giving $95 \%$ confidence that they lie within $1.6 \mathrm{cM}$ (probably within a few megabases). The placement of At-3, Spna-1, and $T g f b-2$ relative to other chromosome 1 markers on the interspecific and composite intraspecific backcross maps (see Dickinson et al. 1990) places Hlx well below the loci for the En-1 (Hill et al. 1987; Joyner and Martin 1987) and Oct-1 (Hsieh et al. 1990) homeo box loci. Interspecific backcross analysis on the same panel maps Oct-1 near At-3 (L.D. Siracusa, M. Rosner, M.A. Vigano, D.J. Gilbert, L.M. Staudt, N.G. Copeland, and N.A. Jenkins, in prep.). Because the distal region of mouse chromosome 1 is syntenic with the long arm of human chromosome 1 and human $T g f b-2$ resides at band 1q41 (Barton et al. 1988), the human Hlx gene probably maps in that vicinity.

\section{Hlx-related genes in diverse vertebrates}

To gauge whether other vertebrate genomes contain $H l_{x-}$ related genes, Southern blots of EcoRI-digested genomic DNAs from several species were probed at moderate stringency with the Hlx j15 cDNA (Fig. 7A). This sequence resides entirely within a $6.3-\mathrm{kb}$ murine EcoRI fragment (Fig. 1), but the blot revealed faint additional bands in mouse DNA and several prominent bands in DNA from humans, marsupial possum, chicken, and $\mathrm{Xe}$ nopus. Some of these bands may represent relatives of $H$ Hx rather than homologs, as they were selectively lost after a wash at higher stringency (Fig. 7B). Some were also detected at low stringency by a probe spanning the H2.0 homeo box (the 252-bp MspI fragment; data not
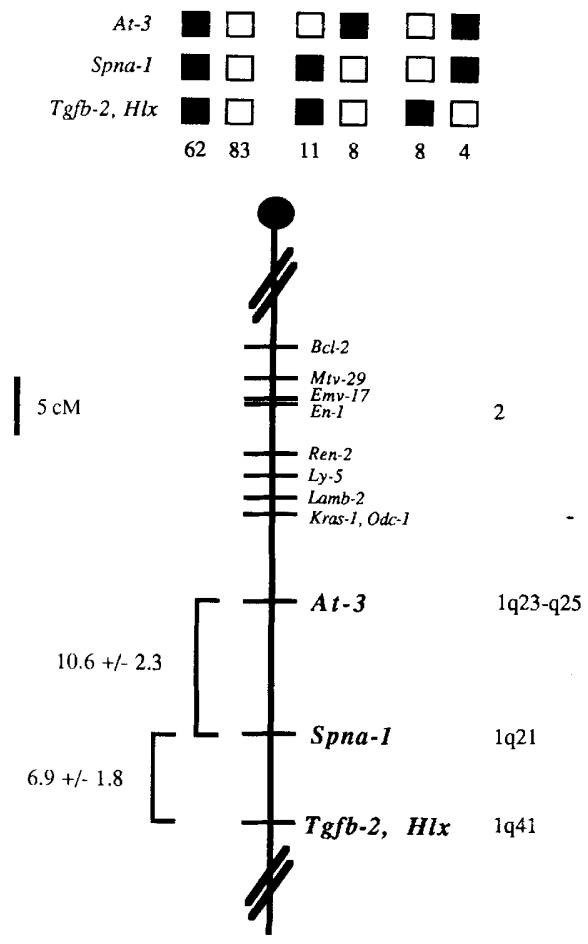

Figure 6. Position of the $H l x$ locus on mouse chromosome 1. The segregation patterns of $H l x$ and three flanking genes, typed in the same 176 backcross animals, is shown at top. Each column represents the chromosome inherited from the [C57BL/6] $\times M$. spretus $\mathrm{F}_{1}$ parent, with a solid box representing a C57BL/6J allele and an open box representing a $M$. spretus allele. The number of offspring inheriting each combination of alleles is listed below each column. The ratios of the number of mice exhibiting recombination between each pair of markers to the total number of mice analyzed for that pair were $19 / 179$ between $A t-3$ and Spna-1; 13/189 between Spna-1 and Tgfb-2 or $H l x$; and $0 / 191$ between $T g f b-2$ and $H l x$. In the partial chromosome 1 linkage map shown, recombination distances between these loci (in $\mathrm{cM} \pm$ S.E.) are shown at left; more proximal markers mapped previously in the interspecific backcross are indicated in smaller type. The positions of several genes on human chromosomes are shown at right. 


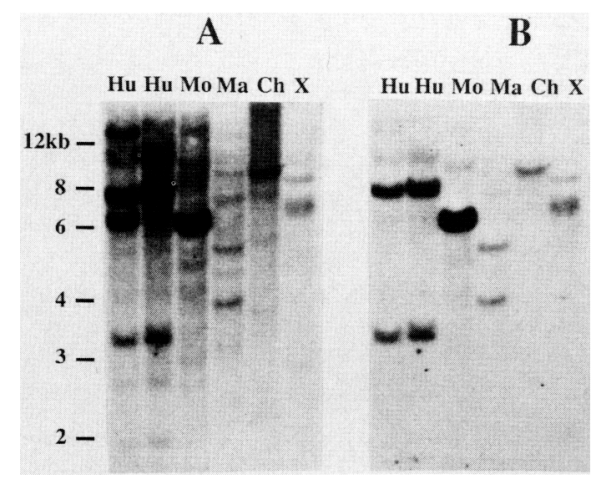

Figure 7. Southern analysis of EcoRI-digested genomic DNA from two humans $(\mathrm{Hu})$, mouse (Mo), marsupial possum Trichosurus vulpecula $(\mathrm{Ma})$, chicken $(\mathrm{Ch})$, and frog Xenopus laevis $(\mathrm{X})$. The probe was the 15 cDNA (Fig. 1). The same blot was washed at low stringency $(A)$ and at moderate stringency $(B)$. Note the polymorphism revealed in the two human samples at low stringency.

shown). These results suggest that a small family of $H l^{x}$ related genes may reside in vertebrate genomes.

\section{Hlx is expressed in particular hematopoietic lineages}

The hematopoietic expression pattern of $H \mathrm{~lx}$ was assessed by Northern blot analysis of poly $(\mathrm{A})^{+}$RNA from 67 hematopoietic cell lines, as well as from spleen and thymus. A representative blot is depicted in Figure 8A, and Table 1 summarizes all of the Northern results. The only $H l x$ RNA detected at high stringency was a $2.7-\mathrm{kb}$ transcript. This species was found at variable levels in all 10 myeloid cell lines examined, including the 4 macrophage lines, which represent the most mature stage of this lineage, and in 17 of 19 lines representing early stages of B-lymphoid development. Interestingly, none of the five plasmacytoma lines examined expressed $H l_{x}$ and three of eight mature $B$ cell lines were also negative. Thus, Hlx expression may be turned off late in B-cell maturation. Consistent with this view, the Hlx transcript level was relatively low in the spleen, which contains B but no pre-B cells. Hlx hematopoietic expression appears to be restricted to the myeloid and B lineages, as none was observed in the 10 erythroid, 12 T-lymphoid, and 3 mast cell lines examined (Materials and methods; Table 1). This pattern contrasts markedly with several Hox genes, which are expressed either ubiquitously or sporadically, if at all, among these lines (Kongsuwan et al. 1988).

The $H l_{x}$ expression pattern seen with the cell lines was confirmed for normal hematopoietic tissues and cell populations by the more sensitive RNase protection analysis (Fig. 8B). Hlx was expressed abundantly in bone marrow and derived myeloid populations, including macrophages grown in macrophage colony-stimulating factor (M-CSF) and a mixed population grown in interleukin-3 (IL-3) that consisted mostly of granulocytes, macrophages, and their precursors. Hlx RNA was also

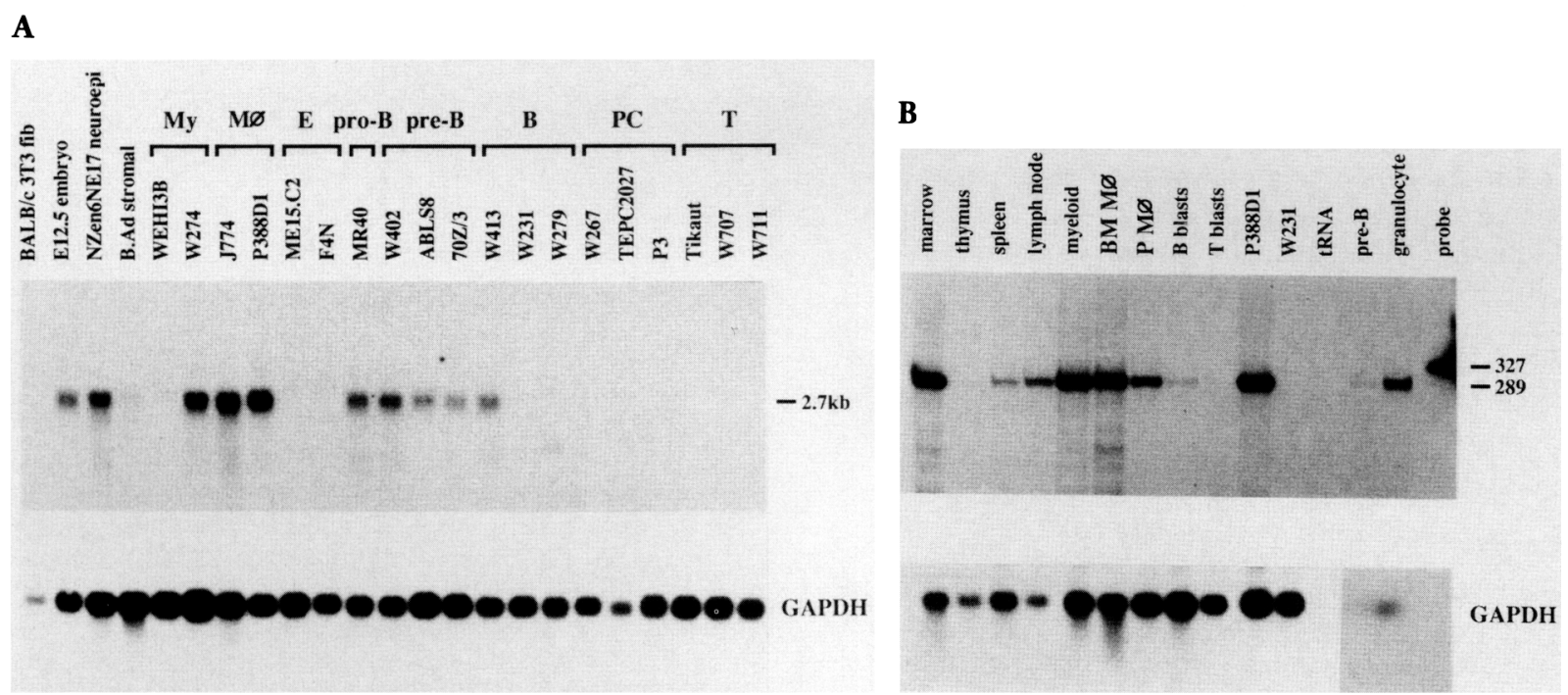

Figure 8. (A) Northern analysis of $H l_{x}$ expression in hematopoietic and nonhematopoietic cell lines and the whole embryo. Cell lines are listed in Table 1 or in Materials and methods. The probe was the 115 cDNA (Fig. 1). The same blot was subsequently hybridized with a GAPDH probe. Note that less poly $(\mathrm{A})^{+}$RNA was loaded for BALB/c fibroblasts. $(B)$ Hlx expression in normal hematopoietic cells and tissues, analyzed by RNase protection. Probe 1 (Figs. 1 and 9) was hybridized to $10 \mu \mathrm{g}$ of total RNA, except for the pre-B cells and granulocytes, for which only 0.5 and $1.0 \mu \mathrm{g}$ of RNA were available. RNA integrity was checked by Northern analysis of equivalent quantities with a rat GAPDH probe. The cell populations, described in Materials and methods, were as follows. The myeloid population consisted of nonadherent IL-3-stimulated bone marrow cells. BM M $\phi$ and P M $\phi$ denote marrow and peritoneal macrophages, respectively. B blasts were LPS-stimulated splenocytes, and T blasts were ConA/IL-2-stimulated splenocytes. The pre-B and granulocyte populations were marrow $\mathrm{B}_{2} 20^{+} / \mathrm{sIgM}^{-}$and GR-1 ${ }^{+}$cells, respectively. The cell lines $\mathrm{P} 388 \mathrm{D} 1$ and W231 provided positive and negative controls. 
Table 1. Expression pattern of Hlx gene

\begin{tabular}{|c|c|c|}
\hline \multicolumn{2}{|l|}{ RNA source } & \multirow{2}{*}{$\frac{H l x \text { mRNA }}{++}$} \\
\hline Whole embryo E12.5 & & \\
\hline \multirow[t]{2}{*}{ Fibroblast } & BALB/c-3T3 & - \\
\hline & $\mathrm{NIH}-3 \mathrm{~T} 3$ & ++ \\
\hline \multirow[t]{3}{*}{ Neuroepithelial } & NZen6NE17 & ++ \\
\hline & NZen6NE7 & ++ \\
\hline & $2.3 \mathrm{D}$ & ++ \\
\hline Stromal & B.Ad & + \\
\hline \multirow[t]{6}{*}{ Myeloid } & FDC-P1 & + \\
\hline & WEHI-3B & + \\
\hline & HI3-22 & ++ \\
\hline & $416 \mathrm{~B}$ & +++ \\
\hline & W274 & +++ \\
\hline & W265 & +++ \\
\hline \multirow[t]{4}{*}{ Macrophage } & $\mathrm{J} 774$ & +++ \\
\hline & P388D1 & $+t+$ \\
\hline & RAW309 & ++ \\
\hline & BA46.3 & ++ \\
\hline Mast & 3 lines & - \\
\hline Erythroid & 10 lines & - \\
\hline Lymphoid stem & $\mathrm{B} 22 \mathrm{M}$ & + \\
\hline \multirow[t]{18}{*}{ Pre-B } & MR2 & ++ \\
\hline & MR17-MES & ++ \\
\hline & MR29 & ++ \\
\hline & MR40 & ++ \\
\hline & W401 & ++ \\
\hline & W402 & ++ \\
\hline & W405 & ++ \\
\hline & W407 & ++ \\
\hline & W410 & $+t$ \\
\hline & W412 & ++ \\
\hline & W414 & +++ \\
\hline & TT28-Ing & + \\
\hline & ABLS-8 & ++ \\
\hline & $18-48$ & - \\
\hline & $18-81$ & - \\
\hline & BA100.5 & ++ \\
\hline & BA41.10 & ++ \\
\hline & $70 Z / 3$ & ++ \\
\hline Spleen & & + \\
\hline \multirow{8}{*}{ B } & W404 & + \\
\hline & W406 & - \\
\hline & W408 & ++ \\
\hline & W411 & $t+$ \\
\hline & W413 & ++ \\
\hline & W417 & + \\
\hline & W231 & - \\
\hline & W279 & - \\
\hline Plasmacytoma & 5 lines & - \\
\hline Thymus & & - \\
\hline $\mathrm{T}$ & 12 lines & - \\
\hline
\end{tabular}

Relative levels of expression of the $2.7-\mathrm{kb} H \mathrm{~lx}$ mRNA were estimated from Northern blots of poly(A) ${ }^{+}$RNA washed at high stringency like those in Fig. 8A. The lines of cell types that did not express $H l_{x}$ are listed in Materials and methods.

abundant in peritoneal macrophages, albeit at a lower level than in their bone marrow counterparts. Although only one-tenth as much RNA was available for analysis from pre-B cells and granulocytes sorted from bone marrow by flow cytometry, it is clear that $H l_{x}$ is expressed at high levels in granulocytes and, allowing for differences in loading (Fig. 8B, GAPDH panel), that its level even in the pre-B population is comparable to that observed in some hematopoietic cell lines. Consistent with a decline in $H l x$ expression during B-cell maturation, low levels were observed in spleen and lipopolysaccharide (LPS)stimulated splenic B-cell blasts. As expected, little $H l_{x}$ RNA was found in thymus, and it was barely detectable in ConA/IL-2-stimulated splenic T-cell blasts.

\section{Embryonic and adult expression pattern}

Hlx expression is not confined to the hematopoietic system. The $2.7-\mathrm{kb} H \mathrm{k}$ mRNA was detected in all three neuroepithelial cell lines examined, in NIH-3T3 fibroblasts, and weakly in a bone marrow stromal cell line (B.Ad) (Fig. 8A; Table 1). Its expression in normal adult tissues was assessed by RNase protection. Hlx mRNA was detectable in all tissues tested, but its level varied greatly (Fig. 9). Among hematopoietic tissues, expression was higher in the spleen and mesenteric lymph nodes than the thymus; but the highest levels were observed in lung, heart, and skeletal muscle; and moderate levels appeared in the small and large intestines, uterus, and ovaries. Only traces were seen in brain, kidney, stomach, and testes. Some of the expression observed could arise from hematopoietic cells. For example, the high level in lung may be attributable, in part, to alveolar macrophages and that in the intestine to the mucosal lymphoid system. Hematopoietic infiltration is not, however,

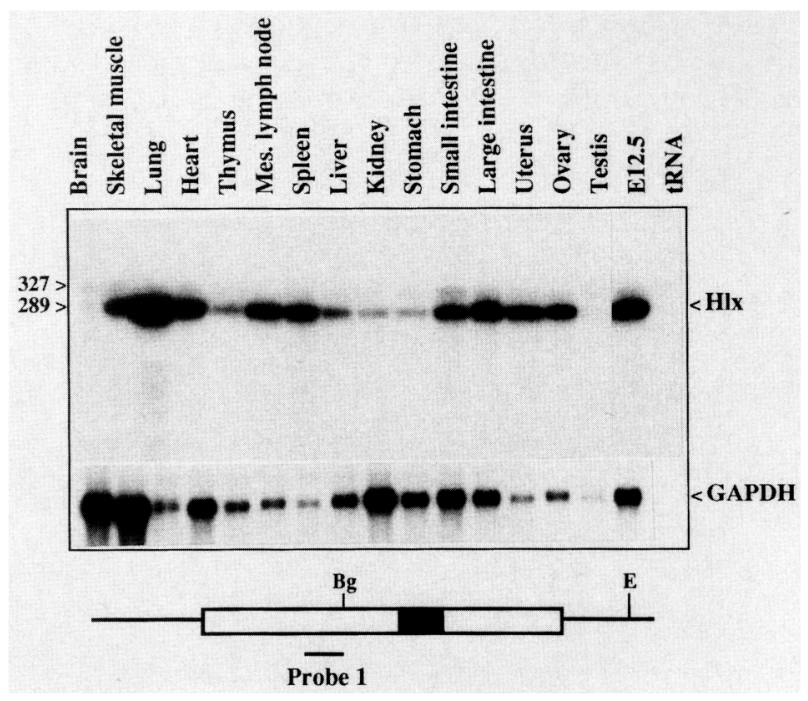

Figure 9. Detection of $H l x$ RNA sequences in adult tissues by RNase protection. Probe 1 was hybridized to $20 \mu \mathrm{g}$ of total RNA from the indicated tissues, from whole 12.5-day p.c. CBA embryos (E12.5), or as a negative control, to $20 \mu \mathrm{g}$ tRNA. The position and size in nucleotides of the full-length probe and the expected RNase-protected $H \mathrm{~lx}$ product are indicated. A trace of undigested probe is evident. Integrity and quantities of RNA were verified by a control Northern analysis with rat GAPDH. 
likely to account for the level seen in skeletal muscle, uterus, or ovaries.

To evaluate whether $H l x$ might have a role in embryonic development, as inferred for many vertebrate homeo box genes, we examined its expression in staged embryos by RNase protection (Fig. 10A). Hlx RNA was detectable at least as early as 8-8.5 days postcoitum (p.c.) in the 1- to 12-somite neurula. Expression of many homeo box genes becomes evident during this period of rapid organogenesis and segmentation (for review, see Holland and Hogan 1988; Kessel and Gruss 1990). By 10.5 days p.c., $H l x$ expression in the whole embryo reached a plateau maintained through at least 16.5 days p.c. The traces also observed in undifferentiated F9 embryonic carcinoma cells and in MBL-1 embryonic stem cells (Fig. 10A) may mean that $H l_{x}$ is expressed even in the inner cell mass of the preimplantation embryo.

Hlx RNA was broadly expressed in 12.5-day p.c. mouse embryos, although again at variable levels within different dissected tissues (Fig. 10B). This level of resolution does not enable us to determine exactly which cell types express $H l x$ or whether expression is lineage specific, position specific, or both. Nevertheless, the higher levels in posterior (e.g., tail and posterior spinal cord) versus anterior (e.g., face and brain) sections may support a role for $H l_{x}$ in establishing positional information. In situ hybridization or immunohistochemistry and functional tests will be necessary to resolve this question.

\section{Discussion}

The novel murine homeo box gene $H l_{x}$ described here differs considerably from the previously described vertebrate Hox genes. Hlx defines a new homeo box gene locus, because the other homeo box genes mapped to murine chromosome 1, En-1 and Oct-1, lie centromeric to the Hlx locus (Fig. 6). None of the known mouse developmental mutants map in the vicinity of $H$ lx.

The very marked similarity of the $H l_{x}$ homeo box to that of Drosophila H2.0 (Fig. 3) is interesting, because H2.0 is one of the few Drosophila homeo box genes exhibiting only tissue-specific expression, although the expression pattern of $H 2.0$, visceral musculature, and its precursors (Barad et al. 1988) is very different from that of $H l x$. In any case, because $H l x$ resembles $H 2.0$ only in the homeo box and a few short additional regions (Figs. 2 and 4), there may well be other Drosophila genes closer to $H l x$. Aside from the homeo box, the most notable region of homology between $H / x$ and $H 2.0$ is the motif denoted the Hep segment, which is also preserved in the Drosophila genes engrailed and invected and, to a much lesser extent, in a murine, two human, and two Drosophila genes bearing the paired box domain (Fig. 5). Conservation within such divergent polypeptides suggests that this segment is likely to represent a new functional motif.

Unlike most vertebrate homeo box genes, $H l x$ has an intron within the homeo box (after amino acid codon 44 of the box). Remarkably, as indicated in Figure 3, its position is the same as that in the homeo box of $H 2.0$ (M. Barad and W. McGinnis, pers. comm.) and five other diverse genes of Drosophila (labial, Distal-less, proboscipedia, Abdominal-B, and $N K-1)$, as well as five less-wellcharacterized genes of $C$. elegans (ceh-1, -2, -7, -9, and -12). This finding may mean that all of these genes reside on the same ancient branch of the homeo box gene evolutionary tree and that other groups can be delineated by introns elsewhere within the box, for example, that after codon 46 of the box in certain even-skipped-like genes (Fig. 3). This simple interpretation must be reconciled, however, both with the fact that an intron is not always present within all members of certain recognized homeo box gene subfamilies and with the considerable diver-
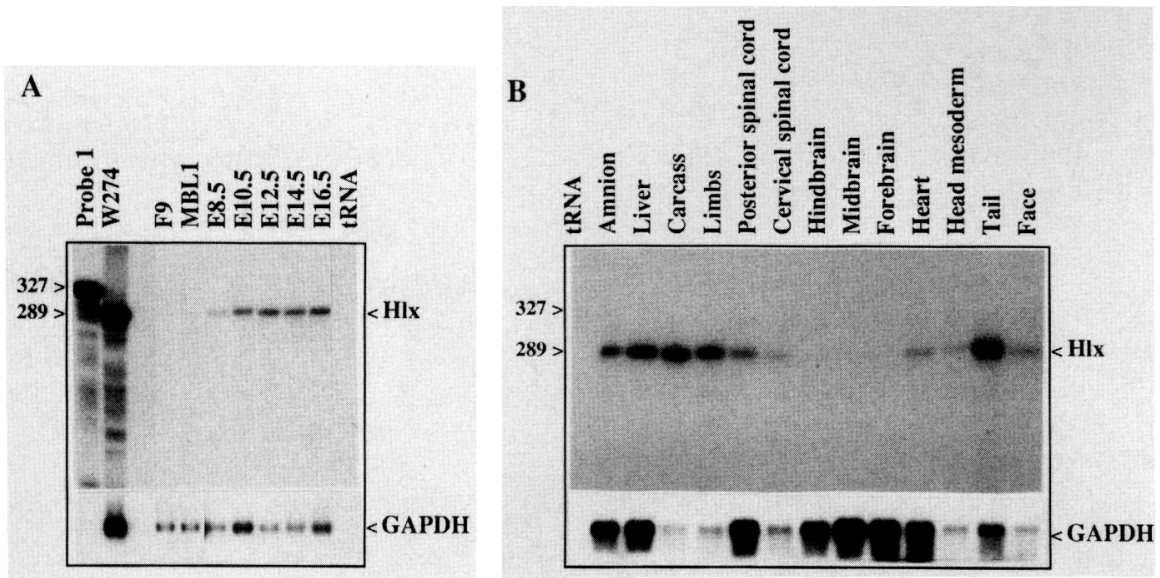

Figure 10. Embryonic Hlx RNA sequences revealed by RNase protection. (A) Probe 1 in Fig. 9 was hybridized to $20 \mu \mathrm{g}$ of total RNA from 8.5- to 12.5-day p.c. CBA mouse embryos; to $1 \mu \mathrm{g}$ of poly $(\mathrm{A})^{+}$RNA from the F9 embryonal carcinoma cell line and the embryonic stem cell line $\mathrm{MBL} 1$; and, as a positive control to $1 \mu \mathrm{g}$ of poly $(\mathrm{A})^{+}$RNA from the W274 myeloid cell line. Undigested probe and a negative control with $20 \mu \mathrm{g}$ of tRNA are also shown. $(B)$ Analysis of RNA from the indicated tissues of E12.5 mice with probe 1. Control Northern analyses with rat GAPDH are shown. 
gence of the homeo box sequences in many of the genes that do contain introns at the same position. Nevertheless, consideration of particular splices within the box versus the more usual splice from 8 to $35 \mathrm{bp}$ upstream from the box may aid in attempts (e.g., Scott et al. 1989) to reconstruct the evolutionary history of this diverse gene family.

Within the hematopoietic compartment, $H l x$ expression appears to be lineage and stage specific, being confined to the myeloid lineage and early stages of B-lymphocyte maturation (Fig. 8; Table 1). Hlx may therefore regulate genes expressed in both of these cell types and contribute to their development. Myeloid and B cells might seem an odd pairing of lineages as $B$ and $T$ lymphocytes share more features, but a similar expression pattern has been reported recently for a transcription factor (PU.1 or Spi-1) bearing an ets-related DNA-binding domain (Klemsz et al. 1990). The B and myeloid lineages might be as close in ontogeny as the $B$ and $T$, because certain progenitor cell lines can generate both $B$ cells and macrophages (Kinashi et al. 1989) and some B lymphoid tumor lines can yield myeloid derivatives (Davidson et al. 1988; Klinken et al. 1988). Alternatively, Hlx might have independent roles within the lymphoid and myeloid lineages.

The expression of Hlx is not confined to the hematopoietic system. Hlx was clearly expressed in three neuroepithelial cell lines and a fibroblast line (Fig. 8A; Table 1), in several adult tissues where infiltration by hematopoietic cells is unlikely to be significant, and also in the embryo (see below). In our view, these findings do not argue against a regulatory role for $H l x$ within the hematopoietic compartment. Certain Drosophila homeo box genes function in more than one context, for example, ftz in both segmentation and neurogenesis, and increasing evidence suggests that this holds for vertebrate transcription factors as well. For instance, the "lymphoid-specific" Oct-2 homeo protein is detectable within several types of hematopoietic cells that do not transcribe immunoglobulin genes (Cockerill and Klinken 1990), and Oct-2 mRNA was found in the embryonic brain (He et al. 1989). Similarly, expression of LF-B1, initially thought to be liver specific, is found also in the kidney, intestine, and spleen (Baumhueter et al. 1990). Given the compelling evidence for combinatorial action of many transcription factors (Mitchell and Tjian 1989; Scott et al. 1989|, the same factor might well have a regulatory role in more than one lineage.

Hlx is expressed from an early stage of development (Fig. 10A) and broadly in dissected tissues of day-12.5 embryos (Fig. 10B). Notable features of the transcript distribution in these embryos are very low expression in the brain, with more robust expression in the spinal cord, similar to many of the Hox genes that have anterior expression boundaries posterior to the hindbrain (for review, see Holland and Hogan 1988; Kessel and Gruss 1990). Higher levels of expression in posterior versus anterior tissues may indicate a role for Hlx in the development of posterior structures or in axis formation, as proposed for the Hox genes. Preliminary in situ hybridiza- tion data confirm the posterior localization of $H l_{x}$ mRNA, and we are currently raising antisera to $H l_{x}$ fusion proteins to allow a detailed analysis of $H / x$ protein distribution.

$H l x$ adds to the growing list of divergent homeo box genes identified recently in the mouse. In addition to En-1 and En-2 (Joyner and Martin 1987), the POU class, which may number at least eight members ( $\mathrm{He}$ et al. 1989|, and the several paired-like genes (Kessel and Gruss 1990), these include LF-B1, TTF-1, and Isl-1 (see introductory section), $C d x-1$ (Duprey et al. 1988), Hox-7 (Robert et al. 1989), and prl (Kamps et al. 1990). Moreover, the four better-studied Hox loci probably contain at least 40 genes. Although the total number of murine homeo box genes is difficult to estimate, if one extrapolates from C. elegans, where some $1 \%$ of the total genes appear to be of this class (Bürglin et al. 1989), only a small proportion of the murine repertoire may have been isolated. In any case, the regulatory potential of this increasingly diverse family clearly is immense.

\section{Materials and methods}

\section{Hybridization and cloning}

The four oligonucleotide probes comprised degenerate 36-mers representing consensus sequences across the third helix region in the Antp, paired, bicoid, and even-skipped homeo boxes (Kongsuwan et al. 1988). The 70Z/3 cDNA library in $\lambda$ gtll (BenNeriah et al. 1986) was kindly provided by Dr. D. Baltimore. Phage DNA adsorbed to nitrocellulose filters (Schleicher \& Schuell) was hybridized overnight at room temperature with ${ }^{32} \mathrm{P}$-end-labeled oligonucleotides, each at $10^{6} \mathrm{cpm} / \mathrm{ml}$, in $50 \%$ formamide, $5 \times$ SSC, $5 \times$ Denhardt's solution, $0.1 \%$ SDS, and $100 \mu \mathrm{g} / \mathrm{ml}$ of denatured sheared herring sperm DNA. Filters were washed in $2 \times \mathrm{SSC}, 0.1 \% \mathrm{SDS}$, at $42-50^{\circ} \mathrm{C}$, as required to reduce background. The random-primed macrophage library was prepared by Dr. Jane Visvader in Lambda Zap II (Stratagene) from poly $(\mathrm{A})^{+}$RNA of normal murine bone marrow macrophages. Phage DNA adsorbed to Amersham Hybond-C Extra membranes was probed with the 15 cDNA (Fig. 1), labeled with ${ }^{32} \mathrm{P}$ by random priming (Bresatec). Hlx clones represented $0.006 \%$ of the plaques.

$H$ lx genomic clones were identified by hybridization of the j15 cDNA (Fig. 1) to $10^{6}$ phage plaques from a genomic library of $\mathrm{BALB} / \mathrm{c}$ mouse DNA (from plasmacytoma ABPC17) constructed in $\lambda E M B L 3$ (Corcoran et al. 1985). Hybridizing phage were purified, the DNA restriction mapped, and the region hybridizing to the cDNA probe delimited to a 6.3-kb EcoRI fragment (Fig. 1). This was subcloned into pSP72, and a series of nested deletions generated by exonuclease III digestion (Henikoff 1987) were subcloned into $\mathrm{M} 13 \mathrm{mp} 18$ and sequenced to position the introns within the gene.

Genomic Southern blots were hybridized at $42^{\circ} \mathrm{C}$ in $40 \%$ formamide, $5 \times$ SSC, $5 \times$ Denhardt's solution, $0.1 \%$ SDS, and $100 \mu \mathrm{g} / \mathrm{ml}$ of sheared denatured herring sperm DNA. Low-stringency washing was done in $2 \times \mathrm{SSC}$ at $50^{\circ} \mathrm{C}$; moderate-stringency washing was done in $1 \times \mathrm{SSC}$ at $65^{\circ} \mathrm{C}$.

\section{Chromosomal localization}

Interspecific backcross progeny were generated by mating (C57BL/6J $\times$ M. spretus) $\mathrm{F}_{1}$ females and C57BL/6 J males (Buch- 
berg et al. 1988). DNA isolation, restriction enzyme digestion, Southern blotting, and hybridization were performed essentially as described (Jenkins et al. 1982). All blots were on Zetabind nylon membrane (AMF-Cuno). The Hlx probe, the $\mathrm{j} 15$ cDNA clone (Fig. 1), was labeled with $\left[\alpha{ }^{32} \mathrm{P}\right] \mathrm{dCTP}$ by nick translation (Amersham kit). Washing was done to a final stringency with $0.5 \times$ SSCP and $0.1 \%$ SDS at $65^{\circ} \mathrm{C}$. TaqI generated $H l x$ fragments of $5.4,1.9$, and $0.9 \mathrm{~kb}$ from C57BL/6J DNA and of $2.8,1.9$, and $0.9 \mathrm{~kb}$ from $M$. spretus DNA. Probes and restriction fragment length polymorphisms (RFLPs) for the loci linked to the $H l x$ gene have been described (Dickinson et al. 1990). Recombination distances were calculated as described /Green 1981) by using the computer program SPRETUS MADNESS developed by D. Dave (Data Management Services, Frederick, MD) and A.M. Buchberg (National Cancer Institute-Frederick Cancer Research and Develpment Center and ABL-Basic Research Program, Frederick, MD). Gene order was determined by minimizing the number of recombination events required to explain the allele distribution patterns.

\section{RNA preparation, Northern analysis, and RNase protection}

Poly $(A)^{+}$RNA was isolated from cells and tissues by proteinase $\mathrm{K} / \mathrm{SDS}$ digestion and oligo(dT)-cellulose chromatography. RNA $(4 \mu \mathrm{g} / \mathrm{lane})$ was fractionated on $1 \%$ agarose gels containing 0.22 $M$ formaldehyde, $20 \mathrm{~mm}$ MOPS (pH 7), $1 \mathrm{mM}$ EDTA, $5 \mathrm{~mm}$ sodium acetate, and $0.5 \mu \mathrm{g} / \mathrm{ml}$ of ethidium bromide. Gels were destained in water for $1 \mathrm{hr}$, photographed under UV illumination to check RNA quantity and integrity and the position of RNA size markers, and blotted onto nylon membranes (Amersham Hybond-N). Hybridization was carried out at $42^{\circ} \mathrm{C}$ overnight with $1 \times 10^{6}$ to $5 \times 10^{6} \mathrm{cpm} / \mathrm{ml}$ of probe in $50 \%$ formamide, $5 \times$ SSC, $5 \times$ Denhardt's solution, $0.1 \%$ SDS, $100 \mu \mathrm{g} / \mathrm{ml}$ of denatured sheared herring sperm DNA, and $40 \mu \mathrm{g} / \mathrm{ml}$ of tRNA. Final washes were at $65^{\circ} \mathrm{C}$ in $0.1-0.2 \times$ SSC and $0.1 \%$ SDS. Subsequently, the quantity of mRNA per track was checked with a GAPDH probe.

RNase protection experiments were carried out essentially as described by Krieg and Melton (1987). A pSP73 plasmid containing the HaeII-BglII fragment of Hlx cDNA (nucleotides 7631053) was linearized with HindIII, and [ ${ }^{32}$ P]UTP-labeled antisense RNA was synthesized with SP6 RNA polymerase. The probe (denoted probe 1 in Figs. 1 and 9) was hybridized to either poly $(\mathrm{A})^{+}$RNA from cell lines or total RNA from tissues, extracted by the method of Chomzynski and Sacchi (1987). Adult tissues were from $(\mathrm{C} 57 \mathrm{BL} / 6 \times \mathrm{SJL}) \mathrm{F}_{1}$ mice. To minimize lymphoid contamination, Peyer's patches were removed from the small intestine prior to extraction. Integrity and quality of RNA samples was verified by gel electrophoresis and ethidium bromide staining, followed by Northern blotting and probing with rat GAPDH.

\section{DNA sequencing}

DNA fragments were subcloned into M13mp18 or mp19 and sequenced with Sequenase (U.S. Biochemicals), using either M13 primers or appropriate specific oligonucleotide primers. Candidate homeo box cDNA clones were first examined by sequencing from an Antennapedia homeo box consensus antisense primer (CGCCGGTTCTGGAACCA). Some sequencing was done from double-stranded plasmid template [pGEM3Zf(+1, Promega]. Taq polymerase (U.S. Biochemicals) was used to confirm the difficult GC-rich $5^{\prime}$ sequences of the cDNA. The composite cDNA sequence was obtained by sequencing both strands, and at least one strand was checked with deoxyinosine nucleotide analogs to reveal and resolve gel com- pressions. The genomic sequence was determined on one strand, as that sufficed to delineate the intron boundaries.

\section{Cell lines and preparation of normal cell populations}

Most of the cell lines have been cited in previous studies (Culvenor et al. 1981; Kongsuwan et al. 1988). For brevity, lines of cell types that did not express $H l x$ were not listed in Table 1. They include the mast cell lines P815, HC.3, and BA96; the erythroid lines F4N, J2E, BA3, BA33, BA42, ME3, ME5, ME14, ME15.C2, and ME17.E8; the plasmacytoma lines MPC11, P3, TEPC2027, AT9, and WEHI267; and the T-lymphoid cell lines Tikaut, ST4, EL4, S49.1, BA34, WEHI7.1, WEHI112.1, WEHI701, WEHI703, WEHI707, WEHI708, and WEHI711. Many of the lines were generated at The Walter and Eliza Hall Institute. For instance, the neuroepithelial lines (Bernard et al. 1989), the BA lines (Elefanty et al. 1990), and the ME fetal erythroid lines (Cory et al. 1991) were produced by retroviral transformation. The WEHI400 series lines (and TT28) were established from B lymphomas of $E_{\mu}-m y c$ transgenic mice, the WEHI700 series from thymomas in $\mathrm{E} \mu-\mathrm{N}$-ras transgenic mice, and the early $B$ lymphoid MR lines from lymphomas of E $\mu$-myc/N-ras mice (Harris et al. 1988).

Hematopoietic tissues were from $(\mathrm{C} 57 \mathrm{BL} / 6 \times \mathrm{SJL}) \mathrm{F}_{1}$ males. Cell populations were characterized by staining and microscopy or, where indicated, flow cytometry. Pre-B cells $\left(\mathrm{B}_{2} 20^{+} ; \mathrm{IgM}^{-}\right)$ and granulocytes $\left(\mathrm{GR}-1^{+}\right)$were sorted from bone marrow on a Becton-Dickinson FACS II, after lysis of erythrocytes in buffered $0.15 \mathrm{M} \mathrm{NH}_{4} \mathrm{Cl}$, yielding $2.5 \times 10^{6}$ and $4 \times 10^{6}$ viable cells, respectively, for RNA extraction. Other normal cell populations were generated by culture with specific factors in Dulbecco's modified Eagle medium (CSL) and 10\% fetal calf serum (FLOW). A nonadherent mixed myeloid population was grown for 5 days from bone marrow plugs suspended at $5 \times 10^{5}$ cells $/ \mathrm{ml}$ in the presence of 200 units of IL-3/ml, and adherent cells (stroma, fibroblasts, and mature macrophages) were discarded; the population consisted of $70 \%$ granulocytes, $18 \%$ monocytes, and small numbers of erythrocytes, lymphocytes, and megakaryocytes. Essentially pure ( $>99 \%$ ) adherent bone marrow macrophages were generated by culture with $15 \%$ L-cell-conditioned medium as a source of M-CSF (Vairo and Hamilton 1985). Peritoneal macrophages were flushed with $5 \mathrm{ml}$ of phosphate-buffered saline from granulocyte-macrophage colony-stimulating factor (GM-CSF) transgenic mice, which carry large numbers of such cells (Lang et al. 1987); 95\% of the cells were macrophages, and most of the rest were eosinophils. B-cell blasts were obtained by culturing splenocytes at $5 \times 10^{5} / \mathrm{ml}$ in $20 \mu \mathrm{g} / \mathrm{ml}$ of LPS and $50 \mu \mathrm{M} 2$-mercaptoethanol for 3 days; $96 \%$ were B cells $\left(\mathrm{B} 220^{+}, \mathrm{sIgM}^{+}\right), 2-3 \%$ were $\mathrm{T}$ cells $\left(\mathrm{CD} 4^{+}\right.$or $\left.\mathrm{CD} 8^{+}\right)$, and $<1.5 \%$ were macrophages $\left({\mathrm{B} 220^{-}}^{-}, \mathrm{sIgM}^{-}, \mathrm{Mac}^{\mathrm{b}^{\text {bright }}}\right)$. T-cell blasts were grown from splenocytes for 3 days in the presence of $2 \mu \mathrm{g} / \mathrm{ml}$ of Con A and, after expansion, for 2 more days in 100 units of IL- $2 / \mathrm{ml}$, in each case at initial densities of $5 \times 10^{5} / \mathrm{ml}$. This population contained $>97 \% \mathrm{~T}$ cells $\left(\mathrm{Thy}^{-1}{ }^{+}, \mathrm{TCR}^{+}\right.$, almost entirely $\mathrm{CD} 4^{+}, \mathrm{CD} 8^{-}$, and $\mathrm{CD} 4^{-}, \mathrm{CD} 8^{+}$cells in a $1: 2$

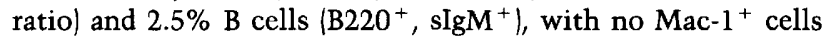
detected.

\section{Acknowledgments}

We are grateful to Drs. M. Barad and W. McGinnis for information on H2.O splicing; Drs. Alan Harris, S. Cory, O. Bernard, A. Elefanty, and A. Perkins for many of the cell lines studied; Dr. Jane Visvader for the macrophage cDNA library; D. Hayman for possum DNA; Dr. L. Williams for EC and ES cell mRNA; and 
D.J. Gilbert, D.A. Swing, and B. Cho for excellent technical assistance. This research was supported by The National Health and Medical Research Council (Canberra, Australia) and by the National Institutes of Health (grants CA 12421 and HD26024 and contract N01-C0-74101 with ABL from the National Cancer Institute). R.P.H. holds a Queen Elizabeth II Fellowship.

The publication costs of this article were defrayed in part by payment of page charges. This article must therefore be hereby marked "advertisement" in accordance with 18 USC section 1734 solely to indicate this fact.

\section{References}

Barad, M., T. Jacks, R. Chadwick, and W. McGinnis. 1988. A novel, tissue-specific, Drosophila homeobox gene. EMBO F. 7: 1251-1261

Barton, D.E., B.E. Foellmer, J. Du, J. Tamm, R. Derynck, and U. Francke. 1988. Chromosomal mapping of genes for transforming growth factors $\beta 2$ and $\beta 3$ in man and mouse: Dispersion of TGF- $\beta$ gene family. Oncogene Res. 3: 323-331.

Bastian, H. and P. Gruss. 1990. A murine even-skipped homologue, $E_{V X} 1$, is expressed during early embryogenesis and neurogenesis in a biphasic manner. EMBO J. 9: 1839-1852.

Baumhueter, S., D.B. Mendel, P.B. Conley, C.J. Kuo, C. Turk, M.K. Graves, C.A. Edwards, G. Courtois, and G.R. Crabtree. 1990. HNF-1 shares three sequence motifs with the POU domain proteins and is identical to LF-B1 and APF. Genes \& Dev. 4: 372-379.

Ben-Neriah, Y., A. Bernards, M. Paskind, G.Q. Daley, and D. Baltimore. 1986. Alternative $5^{\prime}$ exons in c- $a b l$ mRNA. Cell 44: 577-586.

Bernard, O., H.H. Reid, and P.F. Bartlett. 1989. Role of the c-myc and the $\mathrm{N}-m y c$ protooncogenes in the immortalization of neural precursors. I. Neurosci. Res. 24: 9-20.

Boncinelli, E., R. Somma, D. Acampora, M. Pannese, M. D'Esposito, A. Faiella, and A. Simeone. 1988. Organization of human homeobox genes. Hum. Reprod. 3: 880-886.

Bopp, D., M. Burri, S. Baumgartner, G. Frigerio, and M. Noll. 1986. Conservation of a large protein domain in the segmentation gene paired and in functionally related genes of Drosophila. Cell 47: 1033-1040.

Buchberg, A.M., H.G. Bedigian, B.A. Taylor, E. Brownell, J.N. Ihle, S. Nagata, N.A. Jenkins, and N.G. Copeland. 1988. Localization of Evi-2 to chromosome 11: Linkage to other proto-oncogene and growth factor loci using interspecific backcross mice. Oncogene Res. 2: 149-165.

Bürglin, T.R., M. Finney, A. Coulson, and G. Ruvkun. 1989. Caenorhabditis elegans has scores of homeobox-containing genes. Nature 341: 239-243.

Burri, M., Y. Tromvoukis, D. Bopp, G. Frigerio, and M. Noll. 1989. Conservation of the paired domain in metazoans and its structure in three isolated human genes. EMBO $J$. 8: $1183-1190$.

Celniker, S.E., D.J. Keelan, and E.B. Lewis. 1989. The molecular genetics of the bithorax complex of Drosophila: Characterization of the products of the Abdominal-B domain. Genes \& Dev. 3: 1424-1436.

Chomzynski, P. and N. Sacchi. 1987. Single-step method of RNA isolation by acid guanidinium thiocyanate-phenol-chloroform extraction. Anal. Biochem. 162: 156-159.

Cockerill, P.N. and S.P. Klinken. 1990. Octamer-binding proteins in diverse hemopoietic cells. Mol. Cell. Biol. 10: 12931296.

Cohen, S.M., G. Brönner, F. Küttner, G. Jürgens, and H. Jäckle. 1989. Distal-less encodes a homeodomain protein required for limb development in Drosophila. Nature 338: 432-434.

Coleman, K.G., S.J. Poole, M.P. Weir, W.C. Soeller, and T. Kornberg. 1987. The invected gene of Drosophila: Sequence analysis and expression studies reveal a close kinship to the engrailed gene. Genes \& Dev. 1: 19-28.

Corcoran, L.M., S. Cory, and J.M. Adams. 1985. Transposition of the immunoglobulin heavy chain enhancer to the myc oncogene in a murine plasmacytoma. Cell 40: 71-79.

Cory, S., T. Maekawa, J. McNeall, and D. Metcalf. 1991. Murine erythroid cell lines derived with c-myc retroviruses respond to leukemia inhibitory factor, erythropoietin and interleukin-3. Cell Growth Differ. 3 (in press).

Culvenor, J.G., A.W. Harris, T.E. Mandel, A. Whitelaw, and E. Ferber. 1981. Alkaline phosphatase in hematopoietic tumor cell lines of the mouse: High activity in cells of the B lymphoid lineage. I. Immunol. 126: 1974-1977.

Davidson, W.F., J.H. Pierce, S. Rudikoff, and H.C. Morse III. 1988. Relationships between $B$ cell and myeloid differentiation. J. Exp. Med. 168: 389-407.

Davis, R.L., H. Weintraub, and A.B. Lassar. 1987. Expression of a single transfected cDNA converts fibroblasts to myoblasts. Cell 51: 987-1000.

Dickinson, M.E., M.S. Kobrin, C.M. Silan, D.M. Kingsley, M.J. Justice, D.A. Miller, J.D. Ceci, L.F. Lock, A. Lee, A.M. Buckberg, L.D. Siracusa, K.M. Lyons, R. Derynck, B.L.M. Hogan, N.G. Copeland, and N.A. Jenkins. 1990. Chromosomal localization of seven members of the murine TGF- $\beta$ superfamily suggests close linkage to several morphogenetic mutant loci. Genomics 6: 505-520.

Diederich, R.J., V.K.L. Merrill, M.A. Pultz, and T.C. Kaufman. 1989. Isolation, structure, and expression of labial, a homeotic gene of the Antennapedia Complex involved in Drosophila head development. Genes \& Dev. 3: 399-414.

Dressler, G.R., U. Deutsch, K. Chowdhury, H.O. Nornes, and P. Gruss. 1990. $P a x 2$, a new murine paired-box-containing gene and its expression in the developing excretory system. Development 109: 787-795.

Duprey, P., K. Chowdhury, G.R. Dressler, R. Balling, D. Simon, J.-L. Guenet, and P. Gruss. 1988. A mouse gene homologous to the Drosophila gene caudal is expressed in epithelial cells from the embryonic intestine. Genes \& Dev. 2: 1647-1654.

Elefanty, A.G., I.K. Hariharan, and S. Cory. 1990. bcr-abl, the hallmark of chronic myeloid leukaemia in man, induces multiple haemopoietic neoplasms in mice. EMBO $I$. 9: 1069-1078.

Frain, M., G. Swart, P. Monaci, A. Nicosia, S. Stämpfli, R. Frank, and $\mathrm{R}$. Cortese. 1989. The liver-specific transcription factor LF-B1 contains a highly diverged homeobox DNA binding domain. Cell 59: 145-157.

Gehring, W.J. 1987. Homeo boxes in the study of development. Science 236: 1245-1252.

Graham, A., N. Papalopulu, and R. Krumlauf. 1989. The murine and Drosophila homeobox gene complexes have common features of organization and expression. Cell 57: 367-378.

Green, E.L. 1981. Linkage, recombination, and mapping. In $G e$ netics and probability in animal breeding experiments, pp.77-113. Macmillan, New York.

Guazzi, S., M. Price, M. DeFelice, G. Damante, M.-G. Mattei, and R. DiLauro. 1990. Thyroid nuclear factor 1 (TTF-1) contains a homeodomain and displays a novel DNA binding specificity. EMBO J. 9: 3631-3639.

Hanes, S.D. and R. Brent. 1989. DNA specificity of the bicoid activator protein is determined by homeodomain recognition helix residue 9. Cell 57: 1275-1283.

Harris, A.W., W.Y. Langdon, W.S. Alexander, I.K. Hariharan, H. Rosenbaum, E.L. Vaux, E. Webb, O. Bernard, M. Crawford, 
H. Abud, J.M. Adams, and S. Cory. 1988. Transgenic mouse models for hematopoietic tumorigenesis. Curr. Top. Microbiol. Immunol. 141: 82-93.

Hawkins, N.C. and J.D. McGhee. 1990. Homeobox containing genes in the nematode Caenorhabditis elegans. Nucleic Acids Res. 18: 6101-6106.

He, X., M.N. Treacy, D.M. Simmons, H.A. Ingraham, H.W. Swanson, and M.G. Rosenfeld. 1989. Expression of a large family of POU-domain regulatory genes in mammalian brain development. Nature 340: 35-42.

Henikoff, S. 1987. Unidirectional digestion with exonuclease III in DNA sequence analysis. Methods Enzymol. 155: 156165.

Hill, R.E., A.E. Hall, C.M. Sime, and N.D. Hastie. 1987. A mouse homeo box-containing gene maps near a developmental mutation. Cytogenet. Cell. Genet. 44: 171-174.

Holland, P. and B. Hogan. 1988. Expression of homeobox genes during mouse development: A review. Genes \& Dev. 2: 773781.

Hsieh, C.L., S. Sturm, W. Herr, and U. Francke. 1990. The gene for the ubiquitous octamer-binding protein Oct-1 is on human chromosome 1, region cen-q32, and near $L y-22$ and $L t w$ 4 on mouse chromosome 1. Genomics 6: 666-672.

Ingraham, H.A., R. Chen, H.J. Mangaiam, H.P. Elsholtz, S.E. Flynn, C.R. Lin, D.M. Simmons, L. Swanson, and M.G. Rosenfeld. 1988. A tissue-specific transcription factor containing a homeodomain specifies a pituitary phenotype. Cell 55: 519-529.

Jenkins, N.A., N.G. Copeland, B.A. Taylor, and B.K. Lee. 1982. Organization, distribution, and stability of endogenous ectropic murine leukemia virus DNA sequences in chromosomes of Mus musculus. J. Virol. 43: 26-36.

Joyner, A.L. and G.R. Martin. 1987. En-1 and En-2, two mouse genes with sequence homology to the Drosophila engrailed gene: Expression during embryogenesis. Genes \& Dev. 1: 29-38.

Kamps, M.P., C. Murre, X.-H. Sun, and D. Baltimore. 1990. A new homeobox gene contributes the DNA binding domain of the $t(1 ; 19)$ translocation protein in pre-B ALL. Cell 60: $547-555$.

Karlsson, O., S. Thor, T. Norberg, H. Ohlsson, and T. Edlund. 1990. Insulin gene enhancer binding protein Isl-1 is a member of a novel class of proteins containing both a homeo- and a Cys-His domain. Nature 344: 879-882.

Kessel, M. and P. Gruss. 1990. Murine developmental control genes. Science 249: 374-379.

Kim, Y. and M. Nirenberg. 1989. Drosophila NK-homeobox genes. Proc. Natl. Acad. Sci. 86: 7716-7720.

Kinashi, T., K. Tashiro, K. Inaba, T. Takeda, R. Palacios, and T. Honjo. 1989. An interleukin-4-dependent precursor clone is an intermediate of the differentiation pathway from an interleukin-3-dependent precursor clone into myeloid cells as well as B lymphocytes. Int. Immunol. 1: 13-19.

Klemsz, M.J., S.R. McKercher, A. Celada, D.V. Beveren, and R.A. Maki. 1990. The macrophage and B cell-specific transcription factor PU.1 is related to the ets oncogene. Cell 61: 113-124.

Klinken, S.P., W.S. Alexander, and J.M. Adams. 1988. Hemopoietic lineage switch: v-raf oncogene converts $\mathrm{E} \mu$-myc transgenic B cells into macrophages. Cell 53: 857-867.

Kongsuwan, K., E. Webb, P. Housiaux, and J.M. Adams. 1988. Expression of multiple homeo box genes within diverse hematopoietic lineages. EMBO I. 7: 2131-2138.

Kozak, M. 1987. An analysis of $5^{\prime}$ noncoding sequences from 699 vertebrate messenger RNAs. Nucleic Acids Res. 15: $8125-8148$.
Krieg, P.A. and D.A. Melton. 1987. In vitro RNA synthesis with SP6 RNA polymerase. Methods Enzymol. 155: 397-415.

Lang, R.A., D. Metcalf, R.A. Cuthbertson, I. Lyons, E. Stanley, A. Kelso, G. Kannourakis, D.J. Williamson, G.K. Klintworth T.J. Gonda, and A.R. Dunn. 1987. Transgenic mice expressing a hemopoietic growth factor gene (GM-CSF) develop accumulations of macrophages, blindness, and a fatal syndrome of tissue damage. Cell 51: 675-686.

Metcalf, D. 1988. The molecular control of blood cells. Harvard University Press, Cambridge.

Mitchell, P.J. and R. Tjian. 1989. Transcriptional regulation in mammalian cells by sequence-specific DNA binding proteins. Science 245: 371-378.

Mlodzik, M., A. Fjose, and W.J. Gehring. 1988. Molecular structure and spatial expression of a homeobox gene from the labial region of the Antennapedia-complex. EMBO $J$. 7: 2569-2578.

Müller, M.M., S. Ruppert, W. Schaffner, and P. Matthias. 1988. A cloned octamer transcription factor stimulates transcription from lymphoid-specific promoters in non-B cells. $\mathrm{Na}$ ture 336: 544-551.

Poole, S.J., L.M. Kauvar, B. Drees, and T. Kornberg. 1985. The engrailed locus of Drosophila: Structural analysis of an embryonic transcript. Cell 40: 37-43.

Robert, B., D. Sassoon, B. Jacq, W. Gehring, and M. Buckingham. 1989. Hox-7, a mouse homeobox gene with a novel pattern of expression during embryogenesis. EMBO J. 8: 91-100.

Ruiz i Altaba, A. and D.A. Melton. 1989. Bimodal and graded expression of the Xenopus homeobox gene Xhox 3 during embryonic development. Development 106: 173-183.

Schaller, D., C. Wittmann, A. Spicher, F. Müller, and H. Tobler. 1990. Cloning and analysis of three new homeobox genes from the nematode Caenorhabditis elegans. Nucleic Acids. Res. 18: 2033-2036.

Scott, M.P., J.W. Tamkum, and G.W. Hartzell III. 1989. The structure and function of the homeodomain. Biochim. Biophys. Acta 989: 25-48.

Vairo, G. and N.A. Hamilton. 1985. CSF-1 stimulates $\mathrm{Na}^{+}, \mathrm{K}^{+}$-ATPase mediated ${ }^{86} \mathrm{Rb}^{+}$uptake in mouse bone marrow derived macrophages. Biochem. Biophys. Res. Commun. 132: 430-435.

Wright, C.V.E., K.W.Y. Cho, G. Oliver, and E.M. De Robertis. 1989. Vertebrate homeodomain proteins: Families of regionspecific transcription factors. Trends Biochem. Sci. 14: 5256. 


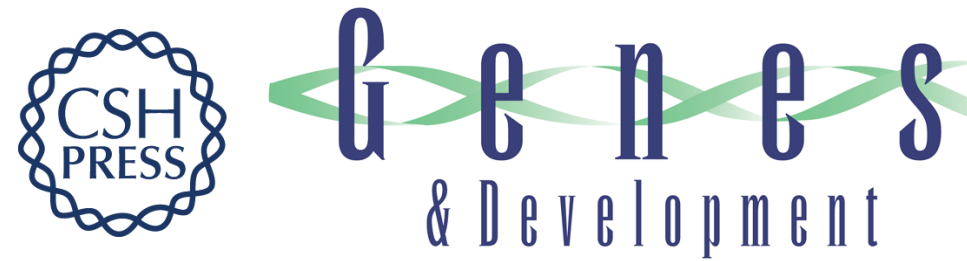

\section{Novel murine homeo box gene on chromosome 1 expressed in specific hematopoietic lineages and during embryogenesis.}

J D Allen, T Lints, N A Jenkins, et al.

Genes Dev. 1991, 5:

Access the most recent version at doi:10.1101/gad.5.4.509

References This article cites 61 articles, 15 of which can be accessed free at:

http://genesdev.cshlp.org/content/5/4/509.full.html\#ref-list-1

License

Email Alerting

Service right corner of the article or click here.

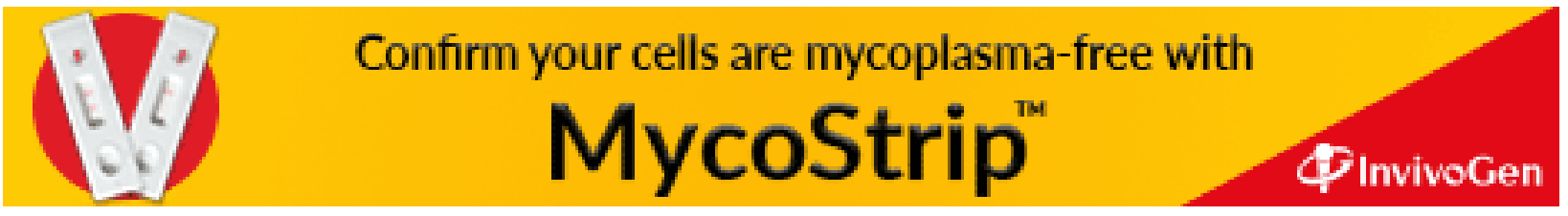

